\title{
Can the Weak Defeat the Strong? Mao's Evolving Approach to Asymmetric Warfare in Yan'an
}

\author{
Andrew Bingham Kennedy
}

\begin{abstract}
Mao's confidence in military confrontations with more powerful adversaries continues to inspire Chinese strategists more than half a century later. This article explores the origins and development of Mao's thinking in this regard, focusing particularly on his years in Yan'an. Drawing on newly available sources, the analysis stresses the importance of experience, as opposed to ideology, in the development of Mao's martial confidence. For much of his time in Yan'an Mao was relatively circumspect in his military ambitions. Yet towards the end of this period his confidence rose considerably after successes against the KMT offensive in 1946. In short, Mao's martial confidence did not spring fully formed from his ideological convictions but emerged over time.
\end{abstract}

In many ways, the revolutionary writings of Mao Zedong seem out of date in today's China. Yet in at least one key respect, Mao's thought remains relevant: his confidence in military confrontations with more powerful adversaries. Indeed, despite impressive gains in military power since 1949, China still faces the prospect of war with more advanced rivals, or "asymmetric conflict" as it is often called. ${ }^{1}$ Some Chinese military writers cite Mao as they revive such slogans as “using the inferior to defeat the superior" (yi lie sheng you 以劣胜优) or “using the weak to defeat the strong" (yi ruo sheng qiang 以弱胜强). ${ }^{2}$ Others explore Mao's writings in more detail as they search for insight into how to prevail over stronger adversaries. ${ }^{3}$ In short, what scholars have called Mao's

1 I use the term "asymmetric conflict" to refer to military competitions in which one side has substantially greater material power than the other. For similar definitions, see Ivan Arreguin-Toft, "How the weak win wars - a theory of asymmetric conflict," International Security, Vol. 26, No. 1 (2001), pp. 94-96; T. V. Paul, Asymmetric Conflicts: War Initiation by Weaker Powers (Cambridge: Cambridge University Press, 1994), p. 20.

2 For some recent examples, see Zhu Xinmin, "Jianchi yi kexue fazhanguan wei zhidao, dali jiaqiang minbing yubeiyi budui jiceng jianshe" ("Persist in using scientific development concepts as our guide, greatly strengthen the basic construction of the people's militia and reserve units"), Guofang (National Defence) No. 11 (2006), p. 5; Huang Xianzhong, "Zhandou jingshen he kexue jingshen shi duoqu zhanzheng shengli de fabao" ("Fighting spirit and scientific spirit are magic weapons for seizing victory in war"), Xiandai junshi (Contemporary Military Affairs) No. 7 (2005), pp. 12-13. Note that concepts such as "using the inferior to defeat the superior" did not originate with Mao but can be traced to ancient Chinese writings on military conflict, such as Sun Zi's Art of War.

3 Wang Shuomin, "Lun Mao Zedong yi lie sheng you zhanlüe siwei ji qi xianshi yiyi" ("On Mao Zedong's strategic thought about defeating the superior with the inferior and its practical 
"military romanticism" continues to be studied and even celebrated in China today. 4

How did Mao's "romantic" view of military conflict originally emerge? This question is important because it speaks to the origins of a crucial aspect of Mao's worldview. It is hard to imagine Maoist China acting with such remarkable military audacity in the Cold War without a leader with such a keen sense of martial prowess. ${ }^{5}$ Accordingly, if we wish to understand the course that Mao charted for China in world affairs, we need to ask how his confidence in the military sphere first emerged. The aim of this article is not to assess how justified Mao's confidence was, or to explore its precise role in the decision-making process. Instead, the goal is to discern how Mao's martial confidence initially took shape. Understanding the development of Mao's thought in this regard is all the more important in light of the attention his military writings continue to receive in China today.

To illuminate the origins of Mao's sense of martial prowess, it is natural to focus on the revolutionary period, when most of his military writings were produced - and when he faced vastly more powerful Japanese and Nationalist opponents. To date, most studies of the revolution have not focused on this particular question. While some have written about the "Yan'an way," for example, these studies do not delve into Mao's specific military ambitions. ${ }^{6}$ Recent biographies of Mao, as well as documentary studies of the revolution, have illuminated specific military decisions, but these have not sought to offer a general assessment of how his martial confidence developed. ${ }^{7}$ Some of the best Chinese studies of his military thought still fail to ask whether the optimism

footnote continued

significance"), Mao Zedong sixiang yanjiu (Mao Zedong Thought Study), Vol. 21, No. 2 (2004), pp. 7780; Wang Wenrong (ed.), Zhanlüe xue (Strategic Studies) (Beijing: National Defence University Press, 1999), p. 73; Jiang Lei, Xiandai yilie shengyou zhanlüe (Modern Strategy of Pitting the Inferior against the Superior) (Beijing: National Defence University Press, 1997), pp. 87-88, 90-93, 95-98.

4 Stuart R. Schram, The Thought of Mao Tse-Tung (Cambridge: Cambridge University Press, 1989), p. 55; Zhang Shuguang, Mao's Military Romanticism: China and the Korean War, 1950-1953 (Lawrence: University Press of Kansas, 1995).

5 Zhang Shuguang explores how Mao's military romanticism shaped China's bold approach to the Korean War in particular in ibid. On the influence of Mao's martial confidence on PRC foreign policy more generally, see Andrew B. Kennedy, "Dreams undeferred: Mao, Nehru, and the strategic choices of rising powers," PhD dissertation, Department of Government, Harvard University, 2007, pp. 53211.

6 Mark Selden, China in Revolution: The Yenan Way Revisited (Armonk, NY: M.E. Sharpe, 1995). See also David Apter and Tony Saich, Revolutionary Discourse in Mao's Republic (Cambridge, MA: Harvard University Press, 1994).

7 Recent documentary histories include Stuart Schram's Mao's Road to Power series (Armonk, NY: M.E. Sharpe, 1992- ) and Tony Saich, The Rise to Power of the Chinese Communist Party: Documents and Analysis (Armonk, NY: M.E. Sharpe, 1996). Recent biographies include Jung Chang and Jon Halliday, Mao: The Unknown Story (London: Jonathan Cape, 2005); Michael Lynch, Mao (New York: Routledge, 2004); Philip Short, Mao: A Life (New York: Henry Holt, 2000); Ross Terrill, Mao: A Biography (Stanford, CA: Stanford University Press, 1999). Note that Zhang Shuguang does not explore the development of Mao's "romantic" view of combat in his study so much as he documents its various facets. See Mao's Military Romanticism, pp. 12-30. 
of his revolutionary works was sometimes more politically expedient than sincere. $^{8}$

It is tempting to see Mao's approach to military conflict as an outgrowth of his radically "leftist" ideology, starting in the late 1920s. In fact, one recent study has argued that Mao was "too emotionally impulsive and politically radical to be strategically cautious and tactful." believed deeply in the power of revolutionary zeal in armed conflict, particularly after he witnessed the peasant uprisings in Hunan in early 1927. As he wrote at the time, the peasants represented "a force so swift and violent that no power, however great, will be able to suppress it." ${ }^{, 10}$ While Mao soon saw a need for more regular forces as well, this eye-opening experience in his home province clearly laid a foundation for his belief in the ability of the weak to challenge the strong. Nevertheless, he was far from consistently ambitious in the wake of this experience. In fact, there were times in the 1930s when he was more conservative in his military outlook than many of his colleagues, as the following analysis will show. So while Mao's ideological radicalism was undoubtedly important, there is more to the story that remains to be told.

To shed more light on this question, this article explores the development of Mao's martial confidence during the decade he spent in Yan'an (延安), from 1937 to 1947. It assesses his confidence level by exploring the stances that he took in internal deliberations over military strategy, comparing his views in these settings with those of his colleagues and with his public statements as appropriate. The analysis focuses in particular on Mao's views at two critical points during the Yan'an years: the outset of the war against Japan in 1937-38 and the onset of total war with the Kuomintang (KMT) in 1946. To elucidate Mao's views at these two points, this study relies substantially on primary sources that have become available relatively recently, as well as on new contributions to the secondary literature on the revolution. While the historical record remains incomplete, these sources are enormously helpful in illuminating Mao's thinking about the asymmetric conflicts that his party faced at these two crucial moments in the revolution.

Two findings stand out. First, Mao was hardly consistently confident in the asymmetric conflicts of the Yan'an years. He was decidedly circumspect when facing the Japanese in the late 1930s, and he initially hoped merely to survive the Nationalist offensive that was unleashed in mid-1946. While some of Mao's best-known writings from the Yan'an period, particularly "On protracted war," sounded sanguine in certain respects, the most confident passages were written for Moscow's benefit and did not reflect Mao's actual views. Second, Mao's

8 Liao Guoliang et al., Mao Zedong junshi sixiang fazhanshi (The Historical Development of Mao Zedong's Military Thought), 2nd ed. (Beijing: PLA Press, 2001).

9 Michael Sheng, Battling Western Imperialism: Mao, Stalin, and the United States (Princeton, NJ: Princeton University Press, 1999), pp. 12-14, 31-32 in particular. The quotation is at p. 31.

10 "Report on the peasant movement in Hunan," February 1927, in Schram, Mao's Road to Power, Vol. 2, p. 430. 
confidence as a practitioner of asymmetric warfare increased markedly toward the end of his time in Yan'an. As the communists gained experience fighting the KMT in the summer and autumn of 1946, Mao raised his sights from surviving the Nationalist onslaught to conquering all of China. In short, Mao's confident approach to asymmetric warfare was not simply a function of radical ideology. Instead, it developed in fits and starts, and it grew stronger with time in response to specific accomplishments in the revolution.

\section{A Tentative War against Japan}

Shortly after arriving in Yan'an in early 1937, Mao and his colleagues leading the Chinese Communist Party (CCP) came to face a growing threat from Japan. Having occupied Manchuria in 1931, Japanese forces moved south and occupied Beijing, Tianjin and Shanghai in the summer of 1937. Japanese troops were also increasingly aggressive in northern China. By mid-September, Mao believed Japan had between 150,000 and 200,000 soldiers moving into northern China, along four different routes. ${ }^{11}$ In contrast, the CCP's Red Army had little more than 30,000 regular combat soldiers at this point. ${ }^{12}$ The potential threat to the communist position in Shaanxi was clear.

Faced with Japan's increasing assertiveness, the CCP and the KMT concluded a second united front in August 1937. Even so, the renewed alliance with the Nationalists was no panacea for the CCP. Mutual distrust poisoned the relationship, and the CCP was careful to maintain operational control of its own troops, now renamed the Eighth Route Army. By 1938, CCP and KMT forces in northern China were having clashes of their own, even as both sought to resist the Japanese. ${ }^{13}$ In addition, Japan's forces were far superior to those of the Nationalist Army, let alone the CCP's troops. KMT troops often lacked artillery, mortars and even machine guns in adequate numbers and with sufficient ammunition. ${ }^{14}$ In contrast, each Japanese division possessed tanks, trucks, light artillery, and hundreds of light and heavy machine guns - in addition to the air support they received. ${ }^{15}$ As an aide to US General Joseph Stilwell later recalled, "in tanks and ammunition supply Japanese strength was overwhelming; in mobility the Chinese were not even comparable."16

Mao initially favoured sending all CCP troops in north China to the front against the Japanese, but he backed away from this plan once Japan's superior

11 "Guanyu diqing panduan ji wo zhi zhanlüe bushu" ("On the assessment of the enemy's situation and our strategic dispositions”), 17 September 1937, in Mao Zedong junshi wenji (Mao Zedong's Collected Military Writings) (Beijing: Military Sciences Press, 1993), Vol. 2, p. 46.

12 Zhang Guotao, The Rise of the Chinese Communist Party, 1928-1938 (Lawrence, KS: University Press of Kansas, 1972), Vol. 2, p. 531.

13 Nie Rongzhen, Nie Rongzhen huiyilu (The Memoirs of Nie Rongzhen) (Beijing: PLA Press, 1984), Vol. 2, pp. $448-58$.

14 Edward Dreyer, China at War, 1901-1949 (New York: Longman, 1995), p. 181.

15 Frank Dorn, The Sino-Japanese War, 1937-41: From Marco Polo Bridge to Pearl Harbor (New York: Macmillan, 1974), p. 7.

16 Ibid. p. 10. 
might became apparent. ${ }^{17}$ On 1 August 1937, he wrote to Zhou Enlai (周恩来) and other leaders that the CCP should carry out "dispersed guerrilla warfare" against the Japanese invaders and not "concentrate our forces for a campaign." 18 In addition, the CCP should only employ one-third of its forces initially, since otherwise it would be difficult to remain dispersed and they would "easily suffer a concentrated attack by the enemy." Mao continued to stress dispersed, guerrilla tactics in subsequent letters that month. ${ }^{19}$ When CCP leaders met at Luochuan (洛川) at the end of August, Mao still favoured a tentative approach. He reportedly argued that Japan's superior armament meant that its forces could do much more damage to the Red Army than those of the KMT. The CCP should thus resist the temptation to send its soldiers to the front to be anti-Japanese heroes. He proposed instead that the CCP should focus on dispersed guerrilla attacks behind the enemy's front lines. At the same time, it should build up its strength by developing base areas in the enemy's rear. ${ }^{20}$

Mao continued to argue for a restrained approach towards conflict with Japan into late September 1937. At Luochuan, his views had met with some resistance from Zhou Enlai, Zhu De (朱德) and Peng Dehuai (彭德怀), who believed the CCP should confront the Japanese more actively. ${ }^{21}$ Mao was keen to make sure the Red Army commanders did not try to do too much. Writing to Peng Dehuai on 21 September, he argued: "Today the Red Army plays no deciding role in any decisive battle. Nevertheless, it does have its own area of expertise, and in this area it can play a deciding role. This is truly independent and self-reliant guerrilla warfare in the mountainous regions (not mobile warfare)." 22

While this note might sound confident in certain respects, Mao was also making clear the limits of his confidence. He had previously seemed to conflate “guerrilla warfare" (youji zhan 游击战) and "mobile warfare" (yundong zhan 运 动战) in earlier writings that focused on fighting the KMT, so his distinction between the two here is worth noting. ${ }^{23}$ As Mao explained later, mobile warfare resembled guerrilla warfare in its emphasis on mobility and surprise, but involved greater concentrations of troops ranging over larger territories and

17 Yang Kuisong, "Kangri zhanzheng baofahou zhongguo gongchandang duiri junshi zhanlüe fangzhen de yanbian" ("The evolution of the CCP's military strategy after the outbreak of the war of resistance against Japan”), Jindaishi yanjiu (Modern History Research) No. 2 (1988), pp. 106-09. See also Sheng, Battling Western Imperialism, p. 40.

18 "Guanyu hongjun zuozhan de yuanze" ("On the operational principles of the Red Army"), 1 August 1937, in Mao Zedong's Collected Military Writings, Vol. 2, p. 20.

19 Pang Xianzhi (ed.), Mao Zedong nianpu, 1893-1949 (Chronology of Mao Zedong, 1893-1949) (Beijing: Central Documents Press 2002), Vol. 2, p. 12.

20 Otto Braun, A Comintern Agent in China, 1932-1939 (Stanford, CA: Stanford University Press, 1982), pp. 211-13; Zhang Guotao, Rise, Vol. 2, p. 535. See also Pang Xianzhi, Chronology of Mao Zedong, Vol. 2, pp. 14-16. For the resolution produced by the meeting, see Saich, Rise to Power, pp. 791-92.

21 In addition to the sources cited above on Luochuan, see William W. Whitson, The Chinese High Command; A History of Communist Military Politics, 1927-71 (New York: Praeger, 1973), p. 68.

22 "Jianchi duli zizhu de shandi youjizhan yuanze" ("Resolutely maintain the principle of independent and self-reliant guerrilla warfare in the mountainous regions"), 21 September 1937, in Mao Zedong's Collected Military Writings, Vol. 2, p. 53.

23 See "Zhongguo geming zhanzheng de zhanlüe wenti" ("Problems of strategy in China's revolutionary war"), December 1936, in ibid. Vol. 1, pp. 749-54. 
wielding somewhat greater firepower. ${ }^{24}$ As such, mobile warfare had the potential to inflict greater punishment on enemy forces in a given period of time, but required greater organization and co-ordination from above. Mao's note to Peng made clear that he was not sufficiently confident to employ mobile warfare against the Japanese at this time. In fact, he seemed ready to concede that all of north China would be occupied by Japan. ${ }^{25}$

Following Lin Biao's (林彪) successful ambush of Japanese forces at Pingxingguan (平型关) on 25 September, Mao was inspired to be more assertive for a time. On 29 September, he suggested that communist troops could concentrate for combat "if the conditions are truly advantageous," though his "fundamental policy" remained organizing guerrilla forces. ${ }^{26}$ On 13 October, Mao even wrote of co-operating with the KMT in "a mobile war of annihilation against the advancing enemy." 27 However, this more ambitious approach was short-lived. By 20 October, Mao expected the Japanese to take Taiyuan (太原), scattering the Chinese forces north of the city, and began focusing on guerrillastyle resistance once again. ${ }^{28}$ On 13 November, a discouraged Mao wrote: "All the armies in Shanxi have suffered big defeats ... with the regular war over, the only thing left is the guerrilla war, waged primarily by the Red Army.",29

Mao’s conservative approach came under attack after Wang Ming (王明) and several members of the CCP Mission to the Comintern returned from Moscow in late 1937. Wang's Comintern credentials gave him considerable prestige, and at Stalin's urging he argued for more co-operation with the KMT and a more aggressive approach to fighting Japan. Wang won support for both of these positions among the Party leadership at a politburo meeting held from 9 to 14 December. While on the defensive, Mao avoided a confrontation and did not strongly resist Wang's line of argument. ${ }^{30}$ There seem to have been two factors behind Mao's restraint. ${ }^{31}$ First, he was able to reach a limited understanding

24 See "Lun chijiu zhan" ("On protracted war"), May 1938, in ibid. Vol. 2, pp. 325-29.

25 "Zhengge huabei gongzuo ying yi youji zhanzheng wei weiyi fangxiang" ("Guerrilla warfare should be the sole orientation of all the work in north China"), 25 September 1937, in ibid. Vol. 2, p. 57.

26 "Zai huabei jushi weiji qingkuangxia ying jianchi youji zhanzheng fangzhen" ("In the dangerous situation prevailing in North China, we must persist with the guerrilla warfare approach"), 29 September 1937, in ibid. Vol. 2, p. 66.

27 "Guanyu Taiyuan shishouhou huabei zhanlüe bushu de yijian" ("Opinions regarding strategic deployment in North China after the fall of Taiyuan"), 13 October 1937, in ibid. Vol. 2, pp. 82-83.

28 "Rijun zhan Taiyuan hou balujun de zuozhan bushu" ("The operational deployment of the Eighth Route Army after the Japanese Army has occupied Taiyuan”), 20 October 1937, in ibid. Vol. 2, pp. 87-88.

29 "Guoduqizhong balujun zai huabei de renwu" ("Tasks of the Eighth Route Army in north China in the transitional period"). For a similar interpretation of Mao's reaction to Pingxingguan in the weeks that followed, see Gao Hua, Hong taiyang shi zenyang shengqide: Yan'an zhengfeng yundong de lai long qu mai (How the Red Sun Rose: The Origins and Development of the Yan'an Rectification Movement) (Hong Kong: Chinese University Press, 2000), pp. 128-30.

30 In fact, Mao voted to endorse Wang's report to the conference, and he apparently was not responsible for the failure to produce a formal resolution. See Zhang Guotao, Wode huiyi (My Recollection) (Hong Kong: Ming Bao Press, 1974), Vol. 3, p. 1330; Gao Hua, How the Red Sun Rose, pp. 140-41; Sheng, Battling Western Imperialism, p. 46.

31 Yang Kuisong, "Kangzhan shiqi gongchan guoji, Sulian yu Zhongguo gongchandang guanxi zhong de jige wenti" ("Several issues in the relations between the Comintern, the USSR, and the CCP during the war of resistance"), Dangshi yanjiu (Party History Research) No. 6 (1987), pp. 133-34. For more on Mao's limited understanding with Wang on the united front, see "Introduction," in Schram, Mao's Road to Power, Vol. 6, p. xl; and Gao Hua, How the Red Sun Rose, pp. 140-41. 
with Wang on the question of the united front, though important differences remained. Second, while Mao remained sceptical that a more ambitious military posture was wise, Wang's presentation left him too isolated to oppose this line effectively. Wang continued to argue in favour of mobile warfare against Japan well into $1938 .^{32}$

Surprisingly, Mao seems to have supported Wang's bolder military line in the first half of 1938. In January, Stalin dispatched V.V. Adrianov of the Soviet General Staff to Yan'an to discuss building up the Red Army. Adrianov apparently asked Mao about his plans for winning the war, to which Mao replied that the CCP would concentrate large forces to eliminate Japanese troops through mobile warfare. ${ }^{33}$ Subsequently, in an interview with the United Press in February, Mao rejected the charge that the CCP only employed guerrilla tactics against Japan: "Some say that we advocate only guerrilla warfare. This is nonsense. We have always advocated a combination of mobile warfare, positional warfare and guerrilla warfare. At present, mobile warfare should be the primary form of combat, with the other two playing a secondary role. ... As for guerrilla warfare, it is always secondary to other forms of battle." 34 Perhaps feeling he had gone too far, Mao proceeded to say that guerrilla warfare could still play a "crucial strategic role" in this type of war.

In May 1938, Mao laid out a more substantial and long-term vision for defeating Japan in a series of lectures later published as "On protracted war." These lectures have traditionally been seen as defending Mao's emphasis on guerrilla warfare, and in important respects they did. Mao said, for example, that the Eighth Route Army's guiding principle was: "guerrilla warfare is basic, but lose no chance for mobile warfare under favourable conditions." ${ }^{35}$ Yet even here there were hints of a more ambitious line. In particular, Mao saw the war developing in three stages: the enemy's strategic offensive, a prolonged stalemate and finally China's strategic counteroffensive. ${ }^{36}$ He argued that the "primary" (zhuyaode 主要 的) form of warfare in the first stage, which he viewed as ongoing, was not guerrilla warfare but mobile warfare, which could be used to slow or halt Japan's advances. Only during the ensuing stalemate (the second stage) would guerrilla warfare become the main form of fighting. Mao also published another of his most famous military works at this time, the collaborative essay entitled "Problems of strategy in the guerrilla war against Japan." This more focused analysis also touted regular warfare as "primary" and guerrilla warfare as "supplementary" in the war effort. ${ }^{37}$

32 John Garver, Chinese-Soviet Relations, 1937-1945: The Diplomacy of Chinese Nationalism (New York: Oxford University Press, 1988), pp. 71-72.

33 Chang and Halliday, Mao, p. 216. Chang and Halliday's book has been widely criticized, but this particular claim fits with subsequent statements made by Mao, as described below. I could not verify it directly since Chang and Halliday cite a Russian source that is not widely available.

34 "Tong hezhongshe jizhe Wang Gongda de tanhua" ("Interview with United Press reporter Wang Gongda"), February 1938, in Mao Zedong wenji (Mao's Zedong's Collected Works) (Beijing: People's Press, 1993), Vol. 2, p. 100.

35 For example, see "On protracted war," p. 268.

36 "On protracted war," pp. 290-98.

37 "Kangri youji zhanzheng de zhanlüe wenti" ("Problems of strategy in the guerrilla war against Japan”), May 1938, in Mao Zedong's Collected Military Writings, Vol. 2, p. 230. 
Was Mao changing his mind in the first half of 1938 ? It seems not. He continued to stress guerrilla tactics in the orders he issued to his commanders after his February interview with the United Press. ${ }^{38}$ In addition, at a CCP politburo meeting in March, Wang Ming argued that the Red Army should rely primarily on mobile warfare, supported by positional and guerrilla warfare, but no formal resolution was adopted because of Mao's opposition. ${ }^{39}$ After setting out his plan for defeating Japan in May, Mao still stressed guerrilla warfare over mobile warfare in his orders. ${ }^{40}$ Even several years later, after the CCP's forces had grown substantially, Mao continued to focus on guerrilla warfare. ${ }^{41}$

It is true that the CCP did unleash more concentrated attacks against the Japanese in the Hundred Regiments Campaign of 1940. This particular campaign was the brainchild of Peng Dehuai, who launched the attacks without Mao's approval. ${ }^{42}$ Even so, Mao seemed to get caught up in the campaign's early successes, much as he did after Lin Biao's victory at Pingxingguan, and he apparently asked Peng to expand the initiative after it began. ${ }^{43}$ However, Mao later lost enthusiasm for the enterprise after it became a major campaign, and by mid-1941 he was telling Peng not to "fight too fiercely (as in the Hundred Regiments clashes)."44 In 1944, CCP commanders began to experiment with mobile warfare once again, but this trend was not sanctioned by the Party until the Seventh Party Congress in June 1945, when the war was essentially over. ${ }^{45}$ Mao later confirmed that dispersed guerrilla warfare had been primary, and mobile warfare supplementary, during the war against Japan. ${ }^{46}$

38 See, for example, "You jihuade bushu jinyubian de youji zhanzheng" ("Make a planned deployment for guerrilla warfare in the Shanxi-Henan border region"), 6 March 1938, in ibid. Vol. 2, p. 183.

39 Saich, Rise to Power, pp. 670, 803.

40 "Zai huabei xibei fangshou fazhan youji zhanzheng" ("Freely develop guerrilla warfare in north and north-west China"), 15 June 1938, in Mao Zedong's Collected Military Writings, Vol. 2, p. 355.

41 This is not to suggest that Mao's views were entirely static. He eventually became more comfortable with the construction of base areas in the plains as well as in the mountains. See Gregor Benton, New Fourth Army: Communist Resistance Along the Yangtze and the Huai, 1938-1941 (Berkeley: University of California Press, 1999), p. 35.

42 Peng Dehuai, Memoirs of a Chinese Marshal (Beijing: Foreign Languages Press, 1984), p. 438. Lyman Van Slyke finds it unsurprising that Peng moved without Mao's approval, given the difficulty of communications in the field. See Van Slyke, "The battle of the hundred regiments: problems of coordination and control during the Sino-Japanese war," Modern Asian Studies, Vol. 30, No. 4 (1996), pp. 991-92.

43 Peng Dehuai, Memoirs, p. 441. Peng may have been referring to an unsigned directive that appears to have been written by Mao on 10 September 1940. See "Introduction," in Schram, Mao's Road to Power, Vol. 7, p. lxiii.

44 "Yu youjun peihe zuozhan jianjue pohuai di zhi jingong" ("Co-operate with friendly armies in battle, resolutely crush the enemy's attack”), 6 June 1941, in Mao Zedong's Collected Military Writings, Vol. 2, p. 646. Three years later, Mao presided over much harsher criticism of Peng. See Frederick Teiwes, "Peng Dehuai and Mao Zedong," The Australian Journal of Chinese Affairs, No. 16 (1986), p. 86.

45 Whitson, The Chinese High Command, p. 83. For the formal decision to resume mobile warfare, see "Zhongguo gongchandang diqici daibiao dahui guanyu junshi wenti de jueyi (caoan)" ("Seventh congress of the Chinese Communist Party resolution on military issues (draft)"), 11 June 1945," in CCP Central Archives (ed.), Zhonggong zhongyang wenjian xuanji (Selected Documents of the Chinese Communist Party Central Committee) (Beijing: China Central Committee Press, 1991), Vol. 15, pp. $112-14$.

46 "Jizhong youshi bingli, gege jianmie diren" ("Concentrate a superior force to destroy enemy forces one by one”), 16 September 1946, in Mao Zedong's Collected Military Writings, Vol. 3, p. 484. 
In short, notwithstanding his public bravado in the first half of 1938, Mao remained wary of what the CCP could accomplish against Japanese forces throughout much of the war. Yet the question remains: why did Mao express such interest in mobile warfare in the first half of 1938? The answer almost certainly lies in Soviet pressure. As noted above, Stalin was keen to see both the CCP and the KMT fighting hard against Japan, and his wishes were made abundantly clear after Wang Ming arrived in Yan'an. Feeling threatened and eclipsed by Wang, Mao could hardly afford to ignore Stalin's wishes. Mao's remarks to Adrianov, his comments to the press and the ambiguity in his military essays were thus probably designed to placate Moscow. ${ }^{47}$

Mao's rhetorical posturing, however, did not fool Wang Ming or the Soviets. After the publication of "On protracted war," Wang (then in Wuhan) refused to publish the essay in the Xinhua ribao (新华日报), despite continuing pressure from Yan'an. ${ }^{48}$ Wang also sent the essay to Comintern chief Georgii Dimitrov, who agreed that Mao's plan put insufficient pressure on Japan and also refused to print it. ${ }^{49}$ In the end, the Soviets did become more supportive of Mao's leadership in the summer and autumn of 1938, thanks largely to lobbying by Wang Jiaxiang and Ren Bishi in Moscow. ${ }^{50}$ Ren in particular helped persuade the Soviets that Mao's more circumspect military line was appropriate, a point that was reinforced after Wang Ming's ambitious plan to defend Wuhan fell apart in August. Feeling more secure, Mao returned to supporting guerrilla warfare unequivocally in the autumn of 1938. Addressing the Sixth Plenum of the Central Committee in October, he no longer called for mobile warfare in the first stage of the war, as he had done in May. Instead, he merely called for "the creation of guerrilla warfare" against Japan at this time. ${ }^{51}$

Of course, wariness of fighting Japan was not the only reason Mao preferred guerrilla tactics to mobile warfare. Political calculations were at work as well. By focusing on the construction of base areas behind Japanese lines, Mao knew the CCP could build up its strength and improve its position vis-à-vis the KMT. Years later, one of Mao's secretaries would recall a revealing remark Mao made to Lin Biao after the revolution: "Some comrades believed the less land Japan occupied, the better, only later was there unified recognition: allowing Japan to occupy more territory is the only way to love your country. Otherwise, it would

47 For more on Mao's sensitivity to Soviet pressure at this time, see Gao Hua, How the Red Sun Rose, p. 163.

48 Ma Qilin, "Kangzhan chuqi de Wang Ming touxiang zhuyi luxian cuowu" ("The mistaken capitulationist line of Wang Ming at the outset of the war of resistance"), Dangshi ziliao congkan (Compendium of Party History Materials) No. 1 (1981), p. 142.

49 Frederick Teiwes, The Formation of the Maoist Leadership: From the Return of Wang Ming to the Seventh Party Congress (London: Contemporary China Institute, SOAS, University of London, 1994), p. 29.

50 Ibid. pp. 29-30; Gao Hua, How the Red Sun Rose, pp. 164-71.

51 "Lun xin jieduan" ("On the new stage"), 12-14 October 1938, in Mao Zedong ji (Collected Writings of Mao Zedong) (Hong Kong: Modern Historical Materials Supply Press, 1975), Vol. 6, p. 186. Note that these remarks were delivered before Wang Ming left the meeting to attend the National Political Consultative Assembly, which started on 28 October. Mao evidently felt comfortable downplaying mobile warfare even in Wang's presence at this point. 
have become a country that loved Chiang Kai-shek." ${ }^{52}$ This comment, made to close associates in confidence, suggests that Mao saw Japan's invasion as an opportunity to boost the CCP's position in its continuing struggle with the KMT. Yet it would be wrong to conclude that Mao's interest in guerrilla warfare was purely the result of this kind of calculation. As the preceding narrative makes clear, Mao would have been wary of fighting Japan in any case.

Mao's general approach in the war against Japan, then, was cautious and tentative. There was concerted communist resistance to Japan, but it would rarely be as daring as Mao implied in the first half of 1938, even though CCP forces expanded dramatically during the war. Mao believed in the Red Army as a highly capable guerrilla force, but no more than that, at this point in the revolution.

\section{Growing Confidence against the KMT}

In the wake of Japan's surrender, the CCP and the KMT made fitful efforts at peace, interspersed with fighting in Manchuria, before negotiations broke down in June 1946. By this point, communist forces had grown to more than one million troops, though 400,000 of these were not regular combatants. ${ }^{53}$ Despite this growth, the Red Army was still outmanned and outgunned by the Nationalists' forces. The KMT regular army consisted of roughly 3 million troops in mid-1946, though Mao later estimated KMT strength at that point at 4.3 million. ${ }^{54}$ Moreover, the Nationalists were much better equipped with vehicles and heavy weapons, and they even had 1,000 aircraft in their inventory at the time of Japan's surrender. ${ }^{55}$ The post-war Nationalist regime was also backed by Washington and recognized by Moscow. As a result of the latter, Mao expected little material assistance from the Soviet Union in the event of war, though he did hope for diplomatic support. ${ }^{56}$ More broadly, CCP-held areas in mid1946 contained only 130 million people, roughly one-quarter of China's total population at that point, with the Nationalists controlling the rest. ${ }^{57}$

Mao did not want war at this time. As he stressed to Lin Biao and others on 7 June, "our basic principle should be striving for peace without sacrificing our

52 Li Rui, Lushan huiyi shilu (A Faithful Record of the Lushan Meeting) (Beijing: Spring and Autumn Press, 1989), p. 223.

53 US Department of State, China White Paper (Stanford, CA: Stanford University Press, 1967), Vol. 1, pp. 313-14.

54 "Zhongguo junshi xingshi de zhongda bianhua" ("The momentous change in China's military situation"), 14 November 1948, in Mao Zedong Xuanji (Selected Works of Mao Zedong) (Beijing: People's Press, 1960), Vol. 4, p. 1363.

55 Problems with supply and maintenance would reduce the number of effective aircraft considerably during the course of the war. See E. R. Hooton, The Greatest Tumult: The Chinese Civil War, 1936-49 (London: Brassey's, 1991), p. 75.

56 "Zan wu heping xiwang zhunbei quanguo dada" ("With no hope for peace at the moment, prepare for major fighting nationwide"), 25 June 1946, in Mao Zedong's Collected Military Writings, Vol. 3, p. 295. See also "Yi zhanzheng de shengli qu qude heping" ("Using victory in war to obtain peace"), 11 July 1946, in Mao Zedong junshi wenxuan (neibuben) (Selected Military Writings of Mao Zedong (Internal Edition)) (Beijing: PLA Soldiers' Press, 1981), p. 288.

57 Pang Xianzhi, Chronology of Mao Zedong, Vol. 3, p. 100. See also "Guanyu muqian shiju he renwu de baogao" ("Report on the present political situation and our tasks"), 19 June 1946, in He Long junshi wenxuan (Selected Military Writings of He Long) (Beijing: PLA Press, 1989), pp. 233-34. 
core interests; a long war would not be good for us." 58 Accordingly, he hoped to prolong the 15-day cease-fire that had been arranged by American mediator George Marshall, even if only temporarily. ${ }^{59}$ Chiang's peace terms, however, were tougher than Mao could accept. On 17 June, the KMT forwarded a proposal calling for communist withdrawals in Manchuria, including Harbin, which was the only major city held by the communists in the north-east. Mao wrote to Party leaders five days later: "If we do not accept his harsh demands ... Chiang will attack in Manchuria and the rest of the country in early July."60 Mao urged his colleagues to be ready for war.

Once the fighting began, Mao seemed only moderately confident. Rather than seeking Chiang's overthrow, he merely sought to fend off the Nationalist offensive, which would allow the CCP to negotiate peace on more favourable terms. On 19 June, he wrote to Liu Bocheng (刘伯承), Deng Xiaoping, and others:

Today, it looks as if Chiang Kai-shek is preparing for war; this will be difficult to avoid. After the major fighting, which I estimate will take roughly six months, if we have won big victories, then we will be able to bargain for peace; if our victories have equalled our defeats, then it will still be possible to bargain for peace; if they [the KMT] have prevailed, there will be no chance to negotiate peace. ${ }^{61}$

Notably, the most optimistic scenario Mao entertained here was military success followed by a negotiated settlement. There was not even a hint of hope for total victory. In addition, he was quite willing to concede that the CCP might lose. One of Mao's secretaries later said that deciding for war with the KMT in 1946 was one of the two most difficult strategic decisions Mao made in his life. ${ }^{62}$

Mao's goal throughout the first few months of the war remained a negotiated peace. At times, he seemed more confident about accomplishing this objective, particularly on 22 June when he entertained notions of capturing several towns. ${ }^{63}$ The basic goal, however, did not change. On 1 July, he urged his commanders not to attack KMT forces unless they were attacked first. ${ }^{64}$ On 20 July, an inner-Party directive he wrote expressed confidence that they could attain "peace," as opposed to "revolution." 65 The following day, he wrote to Zhou in Nanjing to see if Marshall could be enlisted in an effort to bring about an unconditional cease-fire. ${ }^{66}$

58 Pang Xianzhi, Chronology of Mao Zedong, Vol. 3, p. 89.

59 See, for example, "Li zheng heping zhunbei zai zhan" ("Strive hard for peace, prepare for a resumption of war"), 13 June 1946, in Mao Zedong's Collected Military Writings, Vol. 3, p. 271.

60 "Dongbei ying zhunbei yu tanpan polie shi fensui Jiang Jieshi jingong" ("The north-east should prepare to shatter Chiang Kai-shek's attack when the negotiations break down”), 22 June 1946, in ibid. Vol. 3, p. 286.

61 "Zhunbei duifu Jiang Jieshi dada de zuozhan bushu" ("Prepare to counter Chiang Kai-shek's deployments for large-scale fighting"), 19 June 1946, in ibid. Vol. 3, p. 277.

62 The other was deciding to intervene in the Korean War. See Liao Guoliang et al., The Historical Development of Mao Zedong's Military Thought, p. 380.

63 "Quanju poliehou Taihang he Shandong liangqu de zhanlüe jihua" ("Strategic plan for Taihang and Shandong after the overall situation explodes"), 22 June 1946, in Mao Zedong's Collected Military Writings, Vol. 3, p. 283.

64 Pang Xianzhi, Chronology of Mao Zedong, Vol. 3, p. 102.

65 "Yi ziwei zhanzheng fensui Jiang Jieshi de jingong" ("Smash Chiang Kai-shek's offensive by a war of self-defence"), 20 July 1946, in Mao Zedong's Collected Military Writings, Vol. 3, pp. 354-56.

66 Pang Xianzhi, Chronology of Mao Zedong, Vol. 3, p. 112. 
In September, Mao shifted the CCP's negotiating stance. Writing to Zhou on 6 September, Mao noted that the Nationalist offensive had seized more than 20 communist-held counties, including such important towns as Chengde (承德) and Taierzhuang (台儿庄). ${ }^{67}$ Under these conditions, he argued, an unconditional cease-fire would merely allow Chiang to consolidate his gains before attacking again. Mao thus stated that the CCP should insist that the KMT withdraw from the newly occupied areas and redeploy away from the front lines before agreeing to a truce. While no longer seeking an unconditional cease-fire, Mao was still focused on a negotiated settlement.

In November 1946, Mao raised his sights considerably. In a directive he sent to regional bureaus of the Central Committee on 18 November, Mao referred to the conflict for the first time as "the people's war of liberation" (renmin jiefang zhanzheng 人民解放战争) rather than a “war of self-defence” (ziwei zhanzheng 自卫战争). Also for the first time, he argued that Chiang Kai-shek would be “destroyed" (miewang 灭亡) as a result of the conflict. On 21 November, Mao spelled out his thinking more clearly at a meeting of top Party leaders. Speaking last, he argued that Chiang's current offensive could be defeated, after which the disparity in military power between the two parties could be eliminated. Then, Mao argued, the CCP could surpass the KMT and "overthrow" (dadao 打倒) the Nationalist regime. The communists would first seize Anhui, Henan, Hebei and Gansu, after which they would move on to southern China. This was the first time Mao had proposed overthrowing the regime as the driving purpose of the conflict. ${ }^{68}$

How serious was Mao in proposing this goal? One might easily imagine that he was mainly hoping to boost communist morale at a difficult time. In retreat throughout China, the CCP lost more than 174,000 square kilometres of territory and 165 towns in the second half of $1946 .{ }^{69}$ On 27 September, Mao had told Lu Dingyi (陆定一) to revise an article he was writing, saying: “The central question in the minds of soldiers in the liberated areas at present is whether and how we can win victory. People are especially worried since we have lost some territory." $" 70$ Mao thus told Lu to focus on how the CCP forces could prevail against a superior enemy, which would build confidence, rather than detailing the iniquities of the KMT. Four days later, Mao's headquarters published a decidedly upbeat review of the past three months of fighting. ${ }^{71}$

Nevertheless, Mao's focus on total victory in November seems to have reflected a sincere assessment of the situation. First, he told his fellow CCP leaders not to make the goal public for the moment - a puzzling decision if he

67 Ibid. Vol. 3, pp. 130-31.

68 Ibid. Vol. 3, pp. 150-51. See also Jin Chongji (ed.), Mao Zedong zhuan, 1893-1949 (Biography of Mao Zedong, 1893-1949) (Beijing: Central Documents Press, 1996), pp. 780-82.

69 Odd Arne Westad, Decisive Encounters: The Chinese Civil War, 1946-1950 (Stanford, CA: Stanford University Press, 2003), p. 61.

70 Pang Xianzhi, Chronology of Mao Zedong, Vol. 3, p. 137.

71 "Sange yue zongjie" ("Summary of the past three months"), 1 October 1946, in Mao Zedong's Collected Military Writings, Vol. 3, pp. 503-10. 
mainly sought to boost morale in the communist ranks. As said at the meeting on 21 November: "Should we now propose overthrowing Chiang Kai-shek? We will work towards this end, but we will not make it a slogan. Our slogan will still be re-establishing the positions held at the cease-fire of 13 January and the resolutions of the Political Consultative Conference."72 By keeping his real hopes secret, Mao presumably hoped to avoid provoking anxiety in Nanjing and Washington. In keeping with this approach, when speaking with Western reporters on 9 December, Mao made no mention of overthrowing the Nationalist regime. ${ }^{73}$ Subsequently, an inner-Party directive released on 1 February 1947 referred to nationwide revolution, but not "overthrow" of the KMT. ${ }^{74}$ Mao's remarks at a politburo meeting that same day made it clear that this was no accident: "We still have not proposed overthrowing US imperialism and Chiang Kai-shek, but in actuality we will overthrow them." 75 In the end, Mao waited until 10 October 1947 - the KMT's National Day - to propose publicly the overthrow of Chiang's regime. ${ }^{76}$

Moreover, Mao's new goal did not emerge out of the blue, but instead reflected his ongoing assessment of the conflict. In September 1946, Mao had emphasized to his commanders that it was more important to deplete the enemy's forces than to hold territory. ${ }^{77}$ With this metric for measuring success, Mao actually seemed encouraged by subsequent developments that autumn, despite the CCP's retreat. The three-month review released on 1 October noted that communist forces had shown themselves capable of wiping out 10,000 Nationalist troops with only 2,000 to 3,000 casualties of their own. ${ }^{78}$ On 1 November, Mao received encouraging feedback from Deng Xiaoping and Liu Bocheng. ${ }^{79}$ At the meeting on 21 November, Mao estimated that communist forces had eliminated 38 Nationalist brigades, forcing the KMT to halt its offensive in some areas. In his view, this development proved that Nationalist forces could be eliminated and that the communists could shift the direction of the war in their favour. Mao calculated that if they could destroy a total of 70 to 80 brigades in six to twelve months of fighting, the Nationalist offensive would crumble, and the CCP could go on the attack. ${ }^{80}$

72 Pang Xianzhi, Chronology of Mao Zedong, Vol. 3, p. 151. The PCC had been established on 10 January 1946 in preparation for the formation of a new national government, with representatives from the KMT, the CCP and other popular organizations.

73 Pang Xianzhi, Chronology of Mao Zedong, Vol. 3, pp. 152-53.

74 "Huanying Zhongguo geming de xin gaochao" ("Greet the new high tide of the Chinese revolution"), 1 February 1947, in Selected Works of Mao Zedong, Vol. 4, pp. 1209-16.

75 Pang Xianzhi, Chronology of Mao Zedong, Vol. 3, pp. 167-68.

76 "Zhongguo renmin jiefangjun xuanyan" ("Manifesto of the People's Liberation Army"), 10 October 1947, in Mao Zedong's Collected Military Writings, Vol. 4, p. 290. See also Pang Xianzhi, Chronology of Mao Zedong, Vol. 3, p. 242.

77 "Concentrate a superior force to destroy enemy forces one by one," pp. 482-86.

78 "Summary of the past three months," p. 505.

79 Pang Xianzhi, Chronology of Mao Zedong, Vol. 3, p. 144.

80 Jin Chongji, Biography of Mao Zedong, pp. 781-82. See also Pang Xianzhi, Chronology of Mao Zedong, Vol. 3, p. 151 . 
Mao's new emphasis on total victory also fitted with broader political developments in the autumn of 1946. In mid-November, Chiang convened the National Assembly, which both the CCP and the KMT had earlier agreed to join, but he did so stipulating terms for communist participation that Mao rejected. ${ }^{81}$ Chiang's decision to forge ahead with the drafting of a new constitution without the communists appeared to destroy any lingering chance of reconciliation. ${ }^{82}$ Of course, the importance of this point should not be overstated; while a negotiated settlement now seemed beyond reach, Mao still could have focused on fighting the KMT to a standstill followed by a "cold peace." Perhaps more important, Mao also seemed to see the Nationalist political foundation as weakening at this time. The three-month review on 1 October noted that the Nationalists had resumed conscription and grain levies, which were arousing popular discontent. Mao saw this growing unrest as offering the CCP opportunities to lead mass struggles in KMT-held areas, further destabilizing the Nationalist regime. ${ }^{83}$ Mao was not playing up the Nationalists' vulnerability merely to boost morale, as he made clear at the leadership meeting on 21 November: "We say the Chinese and US reactionaries are strong in appearance but weak in reality, that we should look down on them. This is not only to comfort and encourage ourselves, it has a basis in fact (emphasis added). ${ }^{\prime 84}$ Mao's rising ambitions in the autumn of 1946 thus reflected his sense of the political environment in China as well as his perceptions of military success against the Nationalist offensive.

Admittedly, not all the political trends in the autumn of 1946 ran in the CCP's favour. Among other things, as the Nationalists seized large swathes of countryside from the CCP, peasants sometimes failed to stand with the Party, and rural power structures often reverted to traditional forms quite quickly once communist troops were gone. ${ }^{85}$ Given the CCP's heavy reliance on the countryside for support, this was a worrying development. Even so, Mao was not too pessimistic on this front. The three-month review published 1 October concluded that peasants were standing with the Party wherever land reform had been carried out "radically and thoroughly," in keeping with the Party's directive of 4 May $1946 .{ }^{86}$ While this statement oversimplified matters considerably, the radical line on land reform was sustained into $1947 .{ }^{87}$ At the same time, Mao assured his colleagues that this radical approach need not

81 See Westad, Decisive Encounters, pp. 57-58.

82 Jin Chongji, Biography of Mao Zedong, p. 780.

83 "Summary of the past three months," 506.

84 Pang Xianzhi, Chronology of Mao Zedong, Vol. 3, p. 151. Mao continued to emphasize the KMT's political weakness in subsequent high-level meetings and Party documents in early 1947. See ibid. Vol. 3, p. 167; and "Greet the new high tide of the Chinese revolution," p. 1210.

85 Westad, Decisive Encounters, pp. 61-62.

86 "Summary of the past three months," p. 506. The Central Committee's 4 May directive had called for the more radical approach of appropriating and re-distributing land rather than merely reducing rent and interest.

87 Suzanne Pepper, Civil War in China: The Political Struggle, 1945-1949 (Berkeley: University of California Press, 1980), p. 290. 
prevent the Party from uniting with landlords in the countryside when necessary. ${ }^{88}$

Mao's rising confidence seems to have survived the KMT's capture of Yan'an in March 1947. Initially, he hoped to mount a successful defence of the communist capital. ${ }^{89}$ In keeping with his philosophy of yielding territory when necessary, however, he abandoned the town when confronted with $\mathrm{Hu}$ Zongnan's (胡宗南) superior forces. Subsequently, Mao took a confident line in dealing with $\mathrm{Hu}$ and predicted his defeat. ${ }^{90}$ Mao's apparent confidence in the face of such a setback was probably not contrived, particularly since communist spies had infiltrated Hu's staff and kept the CCP apprised of his movements. ${ }^{91}$

In sum, Mao's confidence in the asymmetric conflict between the CCP and the KMT was far from fully-formed when war broke out in the summer of 1946 . He did not plan to conquer China at that time, but merely sought a respite from fighting without sacrificing the CCP's core interests. Only in November did Mao predict that the CCP would overthrow the Nationalist behemoth. While sensitive to the need to boost CCP spirits, Mao was not exaggerating his level of confidence for instrumental purposes at this time, as he had done in the first half of 1938. Instead, his rising hopes reflected his own calculations, both political and military.

\section{Conclusion}

Mao emerged from Yan'an markedly confident about the CCP's ability to prevail over more powerful opponents, yet he was hardly so sanguine at the outset. The image of Mao as the ever-sure architect of China's revolution is more myth than reality. Faced with the Japanese onslaught in the late 1930s, Mao generally sought to avoid large engagements, preferring small-scale guerrilla warfare. His more confident statements in the first half of 1938 did not reflect his actual thinking, but instead were a response to Soviet pressure. While Mao was inspired to support bolder initiatives after the victory at Pingxingguan and the early successes of the Hundred Regiments Campaign, these spurts of confidence were short-lived. Towards the end of the Second World War, after CCP forces had grown considerably, Mao was ready to embrace the more ambitious form of mobile warfare more consistently. Yet when total war broke out with the KMT in 1946, his first instinct was merely to

88 Pang Xianzhi, Chronology of Mao Zedong, Vol. 3, p. 151.

89 See, for example, "Chen Xie zongdui xunsu jizhong Puxian fujin zhunbei lianxu zhandou" ("Speedily concentrate Chen and Xie's columns near Pu county, prepare for continuous fighting"), 19 December 1946, in Mao Zedong's Collected Military Writings, Vol. 3, p. 585.

90 "Zhiyao dapo $\mathrm{Hu}$ Zongnan jun ji ke gaibian Shaanbei jumian" ("We can change the situation in northern Shaanxi if Hu Zongnan's forces are defeated”), 27 March 1947; "Guanyu xibei zhanchang de zuozhan fangzheng" ("Concept of operations for the north-west theatre"), 15 April 1947, in ibid. Vol. 4, pp. $15-16$ and pp. 37-38, respectively.

91 Westad, Decisive Encounters, pp. 152-54. 
survive. Only after several months of fighting did he set his sights on total victory.

The point here is not to suggest that the notion of Mao's "military romanticism" is mistaken - far from it. Mao emerged from the revolution with enormous martial confidence, particularly as his prediction of total victory was borne out by events. In March 1948, Mao suggested it would be possible to eliminate the entire KMT Army by mid-1951. ${ }^{92}$ Eight months later, he forecast that the CCP would need only "another year or so" to vanquish its opponent. ${ }^{93}$ Subsequently, while summing up the CCP's experience for other communist parties in the summer of 1950, Liu Shaoqi (刘少奇) noted that the CCP had overthrown the KMT after the war against Japan. While editing the letter, Mao made a point of inserting "within five years" into the text. ${ }^{94}$ The CCP had not only won, it had won with amazing alacrity, and Mao was fiercely proud of this fact.

At the same time, it should be clear that scholars cannot take Mao's military writings from the Yan'an period at face value. In some cases, such as "On protracted war," Mao's most confident assertions should be discounted. In others, such as his writings in the summer of 1946, his actual goals need to be clearly discerned. While Mao often expressed hope for "victory" at this time, this did not mean overthrowing the Nationalist regime but merely fending off its offensive and negotiating a settlement. On the other hand, starting in November 1946, Mao's public statements actually understated his confidence. While he was optimistic enough to set his sights on total victory at that point, he would not make this evident in his public statements until almost a year later.

To be clear, this analysis does not seek to endorse Mao's lofty view of himself or his forces at the close of the revolution. As events after 1949 would show, he was quite capable of overestimating what the PLA could accomplish on the battlefield. Instead, this article has sought to trace the development of an important part of Mao's worldview. Mao's strong sense of martial prowess had great consequences for China under his leadership, and it remains relevant in China's military discourse today. This confidence was not simply a function of radical ideology; in many ways it was forged through the experience of the revolution itself.

92 "Guanyu qingkuang de tongbao" ("A circular on the situation"), 20 March 1948, in Mao Zedong's Collected Military Writings, Vol. 4, p. 439.

93 "The momentous change in China's military situation," p. 1364.

94 "Zhongguo gongchandang de lishi jingyan" ("The historical experience of the Chinese Communist Party"), in Jianguo yilai Liu Shaoqi wengao (Liu Shaoqi's Manuscripts since the Founding of the Nation) (Beijing: Central Documents Press, 2005), Vol. 2, p. 298. 